\title{
Impacts of changes in land use and land cover on atmospheric chemistry and air quality over the 21 st century
}

\author{
S. Wu ${ }^{1}$, L. J. Mickley ${ }^{2}$, J. O. Kaplan ${ }^{3}$, and D. J. Jacob ${ }^{2}$ \\ ${ }^{1}$ Atmospheric Sciences Program, Dept. of Geological and Mining Engineering and Sciences, Dept. of Civil and \\ Environmental Engineering, Michigan Technological University, Houghton, MI, USA \\ ${ }^{2}$ School of Engineering and Applied Sciences, Harvard University, Cambridge, MA, USA \\ ${ }^{3}$ ARVE Group, Environmental Engineering Institute, Ecole Polytechnique Fédérale de Lausanne, Station 2, \\ 1015 Lausanne, Switzerland
}

Correspondence to: S. Wu (slwu@mtu.edu)

Received: 16 April 2011 - Published in Atmos. Chem. Phys. Discuss.: 20 May 2011

Revised: 31 January 2012 - Accepted: 6 February 2012 - Published: 14 February 2012

\begin{abstract}
The effects of future land use and land cover change on the chemical composition of the atmosphere and air quality are largely unknown. To investigate the potential effects associated with future changes in vegetation driven by atmospheric $\mathrm{CO}_{2}$ concentrations, climate, and anthropogenic land use over the 21 st century, we performed a series of model experiments combining a general circulation model with a dynamic global vegetation model and an atmospheric chemical-transport model. Our results indicate that climateand $\mathrm{CO}_{2}$-induced changes in vegetation composition and density between 2100 and 2000 could lead to decreases in summer afternoon surface ozone of up to $10 \mathrm{ppb}$ over large areas of the northern mid-latitudes. This is largely driven by the substantial increases in ozone dry deposition associated with increases in vegetation density in a warmer climate with higher atmospheric $\mathrm{CO}_{2}$ abundance. Climate-driven vegetation changes over the period 2000-2100 lead to general increases in isoprene emissions, globally by $15 \%$ in 2050 and $36 \%$ in 2100 . These increases in isoprene emissions result in decreases in surface ozone concentrations where the $\mathrm{NO}_{\mathrm{x}}$ levels are low, such as in remote tropical rainforests. However, over polluted regions, such as the northeastern United States, ozone concentrations are calculated to increase with higher isoprene emissions in the future. Increases in biogenic emissions also lead to higher concentrations of secondary organic aerosols, which increase globally by $10 \%$ in 2050 and $20 \%$ in 2100. Summertime surface concentrations of secondary organic aerosols are calculated to increase by up to $1 \mu \mathrm{g} \mathrm{m}^{-3}$ and double for large areas in Eurasia over the period of 2000-2100. When we use a scenario of future anthropogenic land use change, we find less increase
\end{abstract}

in global isoprene emissions due to replacement of higheremitting forests by lower-emitting cropland. The global atmospheric burden of secondary organic aerosols changes little by 2100 when we account for future land use change, but both secondary organic aerosols and ozone show large regional changes at the surface.

\section{Introduction}

Changes in land cover may have significant consequences for atmospheric composition and air quality. For example, biogenic volatile organic compounds (VOCs; e.g., isoprene and monoterpenes) and nitric oxide (NO) emitted from certain vegetation species are both important precursors for tropospheric ozone (Houweling et al., 1998; Wang et al., 1998), which is both a potent greenhouse gas and an important air pollutant. Biogenic VOCs are also important precursors of secondary organic aerosols (SOA) (Henze et al., 2008; Liao et al., 2007; Racherla and Adams, 2006), which contribute to particulate matter (PM) air quality. Changes in VOC and NO emissions can also affect the abundance of hydroxyl radical $(\mathrm{OH})$, which, as the main oxidizing agent in the atmosphere, regulates the lifetimes of both air pollutants and greenhouse gases. Beyond affecting the emissions of chemically active species, changing land cover also influences the deposition of some air pollutants (such as ozone and PM) and their precursors. For example, denser forests provide more surface area for dry deposition of chemical compounds. 
In the coming decades, increasing atmospheric greenhouse gas concentrations and the resulting climate change may have large impacts on global land cover (Bachelet et al., 2001, 2003; Cox et al, 2000, 2004; Cramer et al., 2001, 2004). For example, increasing atmospheric $\mathrm{CO}_{2}$ concentrations may enhance vegetation growth through $\mathrm{CO}_{2}$ fertilization (Cramer et al., 2001; DeLucia et al., 2005; Nowak et al., 2004), and warmer climates may lead to enhanced growing conditions especially in high-latitude ecosystems. On the other hand, previous studies suggested that decreased precipitation, especially in the low latitudes, could lead to significant dieback of tropical forests (e.g., Cox et al., 2004; Cramer et al., 2001, 2004; Levy et al., 2004). In addition to the effects of climate change and $\mathrm{CO}_{2}$ fertilization, direct human intervention, through, e.g. deforestation and other land use changes (Houghton et al., 2000; Turner et al., 1994, 1995) will significantly alter global land cover. How and to what extent changing land cover and land use will affect atmospheric chemistry and air quality are not well known.

Sanderson et al. (2003) reported that neglecting potential future changes in land cover results in overestimates of $6 \%$ in the projected increase in global isoprene emissions and of 5-30 ppb surface ozone levels due to climate change over the period 1990-2090. Ganzeveld and Lelieveld (2004) found significant effects on atmospheric chemistry from Amazonian deforestation, including strong decreases in ozone dry deposition and isoprene emissions. Lathiere et al. (2005) calculated that tropical deforestation could result in as much as $29 \%$ decrease in global isoprene emissions. Tsigaridis and Kanakidou (2007) estimated that SOA production from biogenic VOCs would triple by 2100 and the SOA burden would more than double. Heald et al. (2008) found that the anthropogenic land use change by 2100 following the IPCC A2 scenario would reduce the global SOA burden by $14 \%$. Jiang et al. (2008) studied the effects of land use change on surface ozone in the Houston, TX, area and found that the land use change would increase the number of extreme ozone days (i.e., those days with daily maximum 8 -h ozone exceeding $84 \mathrm{ppb}$ ) by 2-3 days per summer. Ganzeveld et al. (2010) calculated decreases in global isoprene emissions and increases in boundary layer ozone mixing ratios by up to $9 \mathrm{ppb}$ in response to 2000-2050 changes in land use and land cover.

Most of the previous studies discussed above, except for Sanderson et al. (2003) and Ganzeveld et al. (2010), focused on the effects of anthropogenic land use change on atmospheric chemistry and ignored potential future climate-driven changes in vegetation cover. In this study, we investigate how changes in land use and land cover driven by (a) climate change, (b) increasing atmospheric $\mathrm{CO}_{2}$ concentrations, and (c) anthropogenic land use change all perturb global atmospheric chemistry and air quality. We focus on the effects of land cover and land use change on tropospheric ozone and SOA, since they have important implications for climate and air quality.

\section{Methods: approach and model descriptions}

To quantify the effects of potential changes in land use and land cover on atmospheric chemistry and air quality over the 21 st century, we performed a series of offline coupled model experiments by combining a general circulation model (GISS GCM 3), a dynamic global vegetation model (LPJ DGVM) and an atmospheric chemical transport model (GEOS-Chem CTM). Archived meteorology from the GISS GCM 3 (Rind et al., 2007; Wu et al., 2007, 2008a,b) was used to drive the LPJ DGVM to simulate changes in land cover over the period 2000-2100 associated with climate change. We used the IPCC A1B scenario (IPCC, 2001) for trends in both longlived greenhouse gases and changes in anthropogenic land use (IMAGE-Team, 2001; MNP, 2006).

We used the "qflux" version of the GISS GCM, with a horizontal resolution of $4^{\circ}$ latitude by $5^{\circ}$ longitude and 23 vertical layers in a sigma-pressure coordinate system extending from the surface to $0.002 \mathrm{hPa}$ (Hansen et al., 1984, 1988; Rind et al., 2008). The lowest three layers extend up to 200, 500 , and $1000 \mathrm{~m}$ altitude for a column based at sea level. The same version of the GISS GCM was used in earlier studies investigating the effects of 2000-2050 global change on air quality in the United States (Pye et al., 2009; Wu et al., 2008a,b). Fixed late 20th century land cover was used as a boundary condition for the GISS GCM (i.e. the potential feedback to climate from vegetation change is not accounted for in this study). The LPJ DGVM (Sitch et al., 2003) simulates vegetation cover, density, productivity and a number of other state variables and fluxes driven by climate, soils and atmospheric $\mathrm{CO}_{2}$ concentrations. LPJ represents land cover by simulating the fractional density of nine plant functional types (PFTs) (Fig. 1) in every gridcell.

Simulated monthly mean meteorological fields of temperature, precipitation and cloud fraction for 2000-2100 calculated with the GISS GCM were used to drive LPJ to simulate the changes in land cover due to climate change. Soils data for LPJ came from the FAO Soil Map of the World (FAO, 2000) and atmospheric $\mathrm{CO}_{2}$ concentrations were those prescribed in the IPCC scenario described above. The same GISS GCM meteorology was also used to drive the GEOSChem CTM, using the interface described in Wu et al. (2007, 2008ab). Global maps of land cover in the form of PFT cover fractions simulated by the LPJ model were used as surface conditions in the GEOS-Chem CTM. We separated the effects of climate- and $\mathrm{CO}_{2}$-induced changes in vegetation cover from anthropogenic land-use change with a series of sensitivity experiments.

We used the LPJ model output of fractional vegetation cover and density (expressed as Leaf Area Index, LAI) at $1^{\circ} \times 1^{\circ}$ resolution in latitude and longitude. The $1^{\circ} \times 1^{\circ}$ output from the LPJ model was then regridded to the $4^{\circ} \times 5^{\circ}$ grid we used as input to GEOS-Chem. Monthly mean values for LAI are used to reflect the seasonal variation. For biogenic VOC emissions, we used the MEGAN scheme 


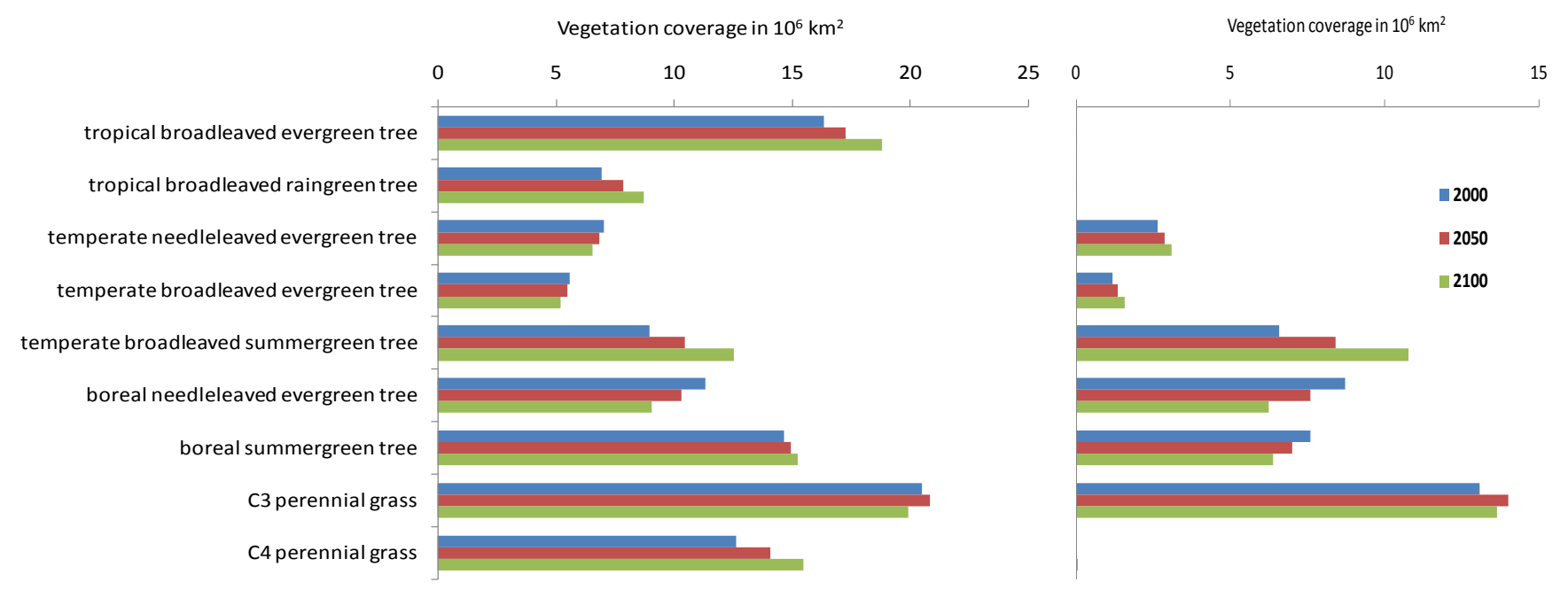

Fig. 1. Global (left) and northern mid-latitude $\left(30-60^{\circ} \mathrm{N}\right)$ areal coverage of various vegetation types for $2000 \mathrm{~s}$, 2050s, and $2100 \mathrm{~s}$ simulated with the LPJ model. Temperate broadleaved summergreen trees Boreal needleleaved evergreen trees Isoprene emissions Ozone dry deposition velocities.

(Guenther et al., 2006), collapsing the 9 LPJ PFTs to the 6 PFTs used by MEGAN (broadleaf trees, needleleaf evergreen trees, needleleaf deciduous trees, shrubs, crops, grass and other). For the purpose of examining the future changes in biogenic emissions associated with land cover change, we assume that the vegetation composition (in terms of biogenic emission rates) for each PFT will remain unchanged since both the MEGAN scheme and the LPJ model resolves the PFTs but not detailed plant species.

We ran LPJ continuously at monthly timestep for the entire period 2000-2100. Because making a continuous simulation with GEOS-Chem for 100 years was computationally infeasible, we chose three decade-long time slices to examine the changes in land use and land cover: 1990-2000, 2040-2050, 2090-2100. Vegetation cover generated by LPJ for each time slice were averaged over the 10 -yr period and applied to GEOS-Chem.

The GEOS-Chem simulation of ozone and aerosols has been extensively evaluated and documented in the literature (e.g., Bey et al., 2001; Fiore et al., 2002a,b, 2003; Hudman et al., 2007; Li et al., 2002, 2004; Park et al., 2004, 2006). GEOS-Chem has detailed and fully coupled ozone- $\mathrm{NO}_{\mathrm{x}}$ VOC-aerosol chemistry with aerosol components including sulfate, nitrate, ammonium, organic carbon, and black carbon (Park et al., 2004), sea salt (Alexander et al., 2005), and dust (Fairlie et al., 2006).

Natural emissions of ozone and aerosol precursors - including non-methane VOCs (NMVOCs) from vegetation, and $\mathrm{NO}_{\mathrm{x}}$ from lightning and soil - are computed locally within GEOS-Chem on the basis of driving meteorological variables. Lightning $\mathrm{NO}_{\mathrm{x}}$ emissions are parameterized as a function of deep convective cloud top (Price and Rind, 1992; Wang et al., 1998) and are distributed vertically following
Pickering et al. (1998). The soil $\mathrm{NO}_{\mathrm{x}}$ emissions are calculated as a function of vegetation type, temperature, precipitation history, and fertilizer usage following Yienger and Levy (1995) with an improved formulation of the canopy reduction factor (Wang et al, 1998). Potential changes in fertilizer and animal manure application associated with future land use change are not considered in this study. The stratosphere-troposphere exchange (STE) of ozone is represented by the Synoz flux boundary condition (McLinden et al., 2000) with an imposed global annual mean STE flux of $500 \mathrm{Tg} \mathrm{yr}^{-1}$. The biogenic emissions of NMVOCs in the model follow the MEGAN scheme developed by Guenther et al. (2006) where the emission fluxes are functions of a number of variables including temperature, solar radiation, leaf area index (LAI) and PFT. Changes in atmospheric $\mathrm{CO}_{2}$ concentrations are likely to affect the isoprene emissions (Arneth et al., 2007; Centritto et al., 2004; Constable et al., 1999; Heald et al., 2009; Possell et al., 2005; Rosenstiel et al., 2003), but these effects are not accounted here.

Dry deposition in GEOS-Chem (Wang et al., 1998; Bey et al., 2001) is based on a resistance-in-series approach (Wesely and Hicks, 1977; Wesely, 1989) with a number of improvements including the explicit dependence of canopy stomatal resistance on LAI (Gao and Wesely, 1995). The dry deposition velocities for each grid box are calculated from the surface layer turbulence and solar radiation. The effect of soil moisture stress on dry deposition (Meszaros et al., 2009; Ganzeveld et al., 2010) is not accounted in this study. Olson land cover classes (Olson, 1992) are used to calculate dry deposition in the standard version of GEOS-Chem; in this study, these ecosystem classes have been reduced to the nine LPJ PFTs. 
Table 1. Changes in biogenic emissions and atmospheric composition ${ }^{\mathrm{a}, \mathrm{b}}$.

\begin{tabular}{|c|c|c|c|c|c|}
\hline \multirow[b]{2}{*}{ Model year } & \multicolumn{3}{|c|}{$\begin{array}{l}\text { Simulations including climate } \\
\text { change and } \mathrm{CO}_{2} \text { trend }\end{array}$} & \multicolumn{2}{|c|}{$\begin{array}{l}\text { Simulations including climate } \\
\text { change, } \mathrm{CO}_{2} \text { trend, and land use change }\end{array}$} \\
\hline & 2000 & 2050 & 2100 & 2050 & 2100 \\
\hline Ozone burden ( $\mathrm{Tg}$ ) & 305 & $304(-0.3 \%)$ & $303(-0.7 \%)$ & $306(+0.3 \%)$ & $304(-0.3 \%)$ \\
\hline SOA burden $(\mathrm{Tg})$ & 0.51 & $0.55(+10 \%)$ & $0.61(+20 \%)$ & $0.48(-6 \%)$ & $0.51(-1 \%)$ \\
\hline Annual isoprene emissions ( $\operatorname{Tg} C)$ & 429 & $469(+10 \%)$ & $532(+25 \%)$ & $410(-5 \%)$ & $465(+8 \%)$ \\
\hline Summer ${ }^{\mathrm{c}}$ isoprene emissions $(\mathrm{Tg} \mathrm{C})$ & 112 & $130(+15 \%)$ & $152(+34 \%)$ & $112(+1 \%)$ & $133(+19 \%)$ \\
\hline Annual monoterpene emissions ( $\operatorname{Tg} \mathrm{C}$ ) & 80 & $83(+4 \%)$ & $88(+10 \%)$ & $86(+7 \%)$ & $90(+12 \%)$ \\
\hline Summer ${ }^{\mathrm{c}}$ monoterpene emissions $(\mathrm{Tg} \mathrm{C})$ & 27 & $28(+3 \%)$ & $29(+8 \%)$ & $29(+8 \%)$ & $31(+13 \%)$ \\
\hline $\mathrm{OH}\left(10^{6}\right.$ molec $\left.\mathrm{cm}^{-3}\right)$ & 1.13 & $1.11(-2 \%)$ & $1.08(-4 \%)$ & $1.13(+1 \%)$ & $1.11(-2 \%)$ \\
\hline
\end{tabular}

a Values are for annual means, unless specified otherwise.

b Values in parentheses denote the percentage change from the 2000 values.

${ }^{\mathrm{c}}$ For Northern Hemisphere summer June-August.

Formation of SOA in the GEOS-Chem model follows the algorithm developed by (Chung and Seinfeld, 2002) for gas-particle equilibrium partitioning between SOA and semivolatile VOC oxidation products. SOA formation from terpenes, alcohols, sesquiterpenes, and isoprene are considered in this study. SOA production from isoprene photooxidation follows the work of Henze and Seinfeld (2006), which is based on chamber experiments of reaction of isoprene with $\mathrm{OH}$ at low $\mathrm{NO}_{\mathrm{x}}$ condition (Kroll et al., 2006). Further details about the SOA formation mechanisms in GEOS-Chem are provided in Liao et al. (2007).

Since this study focuses on the effects due to changes in land use and land cover, we carried out a suite of sensitivity simulations with GEOS-Chem by changing the land use and land cover but not the anthropogenic emissions or climate; i.e. we always use the present-day anthropogenic emissions and meteorology to drive GEOS-Chem. This enables us to separate the effects of land use/land cover change from other effects due to changes in anthropogenic emissions and climate that have been extensively studied in literature (e.g., Johnson et al., 1999; Stevenson et al., 2000, 2006; Hogrefe et al., 2004; Hauglustaine et al., 2005; Brasseur et al., 2006; Racherla and Adams, 2006; Wu et al., 2008ab). Therefore, the possible changes in natural emissions directly driven by climate change (e.g. $\mathrm{NO}_{\mathrm{x}}$ emission from soil is affected by temperature and precipitation while VOC emission from vegetation is sensitive to temperature and solar radiation) are not accounted for in this study.

\section{Results}

\subsection{Impacts of climate- and $\mathrm{CO}_{2}$-driven vegetation change}

We first considered the impacts on atmospheric composition from vegetation change over the period 2000-2100 as a result of climate change and increasing atmospheric $\mathrm{CO}_{2}$ by fixing the spatial pattern of anthropogenic land use at year 2000 conditions. We find that by 2100 temperate forests dominated by broadleaf trees are replacing conifer forests dominated by needleleaf trees (Fig. 2). Globally, we calculated a $40 \%$ increase in spatial coverage of temperate broadleaf trees and a $20 \%$ decrease in boreal needleleaf evergreen trees. The most significant changes in vegetation cover are found over the northern mid-latitudes, where we simulated a $\sim 60 \%$ increase in temperate broadleaf tree cover accompanied by a $\sim 30 \%$ decrease in boreal needleleaf evergreen tree cover and a $15 \%$ decrease in boreal summergreen tree cover (Fig. 1). In addition, we find general increases in forest LAI, except in subtropical regions.

Large increases in global isoprene emissions are calculated in response to these climate-induced vegetation change. We find that the Northern Hemisphere summertime (JuneAugust) global total isoprene emission increases $15 \%$ to $34 \%$ by 2050 and 2100 , respectively (Table 1 ), with the strongest increase over the northern mid-latitudes. The global annual total isoprene emission increases by $10 \%$ and $25 \%$ for 2050 and 2100 respectively. Monoterpene emissions are also calculated to increase with global annual total emissions increasing $4 \%$ to $10 \%$ by 2050 and 2100 , respectively (Table 1). These changes in biogenic emissions indicate that the effects from climate-induced land cover change are comparable to those "direct" effects from climate change driven by changes in temperature and solar radiation. For example, with a similar model set up (GEOS-Chem driven by GISS GCM meteorology), Wu et al. (2008b) previously found that the 2000-2050 climate change would lead to an increase in global isoprene emission by $25 \%$.

Our calculated increase in isoprene emissions is in contrast to Sanderson et al. (2003) who reported a slight decrease of isoprene emissions resulting from climate-driven changes in vegetation cover. The model simulations of Sanderson et 
Temperate broadleaved summergreen trees $\quad$ Boreal needleleaved evergreen trees
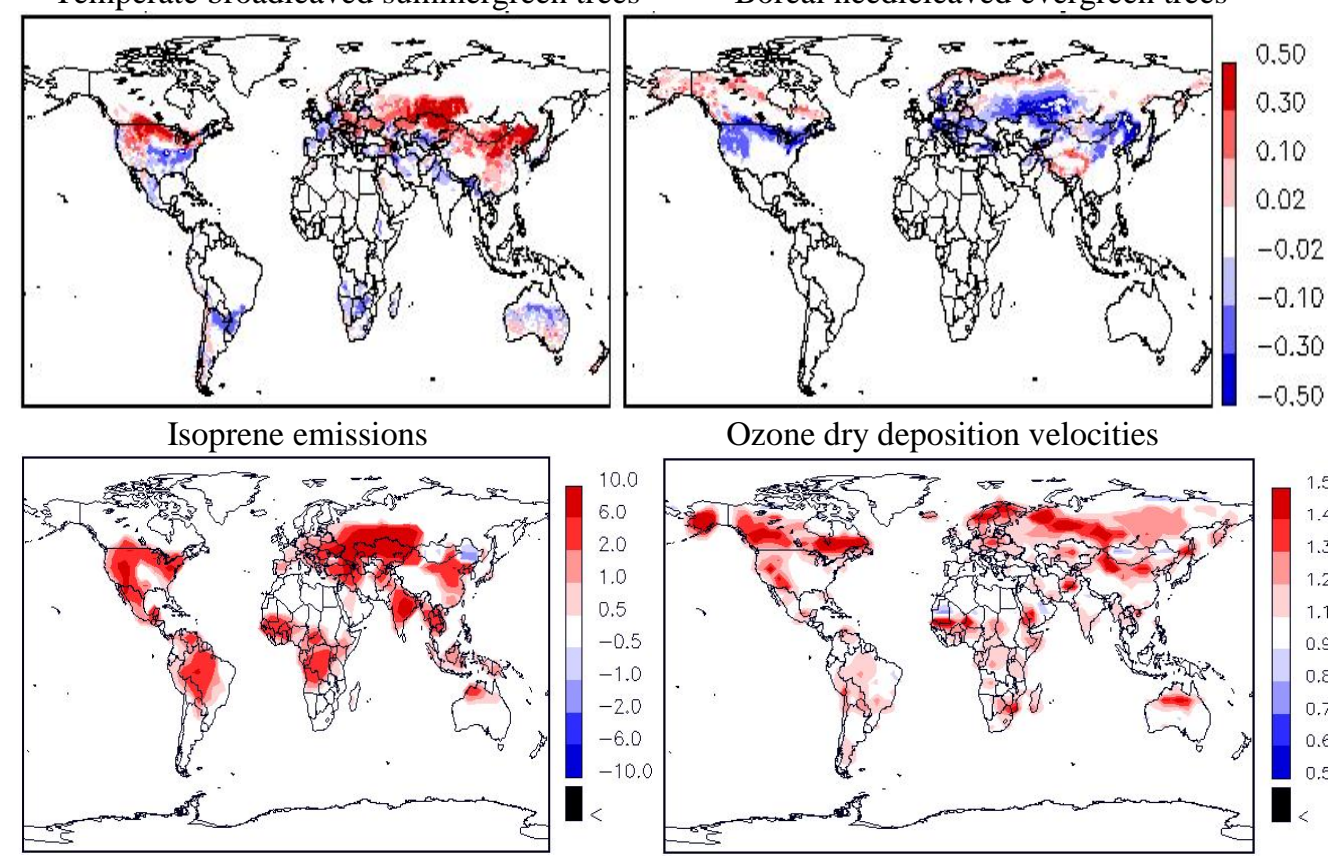

Ozone dry deposition velocities

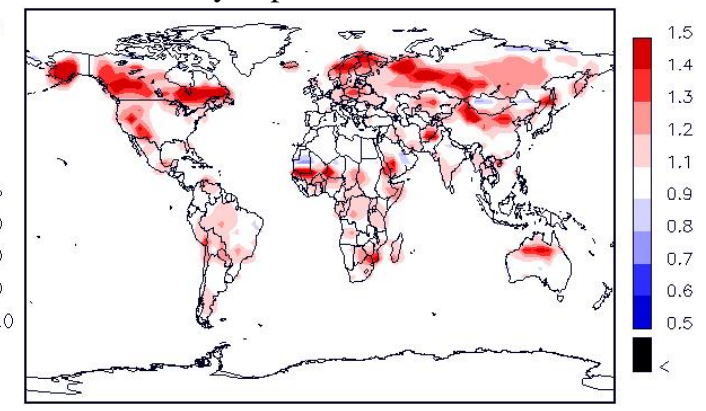

Fig. 2. Model calculated 2000-2100 changes in (upper left) areal fractional coverage of temperate broadleaved trees, (upper right) boreal needleleaved trees, (lower left) isoprene emissions showen as differences (in $10^{11}$ atmos $\mathrm{C} \mathrm{cm}^{-2} \mathrm{~s}^{-1}$ ), (lower right) dry deposition velocities of ozone shown as ratio. Isoprene emissions and ozone dry deposition are based on Northern Hemisphere summer (June-August) values. Color scales are saturated at maximum values.

al. (2003) showed a dieback of large parts of the tropical forests of the Amazon basin between the 1990s and 2090s and ascribed this to be the major driver of the decreasing isoprene emission. We did not see this significant retreat of the Amazon forest in our simulations. This discrepancy is attributed to differences in model treatments of tropical vegetation as well as the simulated meteorology. First, our version of the LPJ model considers the deeply rooted vegetation in the tropics, allowing a maximum soil column of $2 \mathrm{~m}$ (Kleidon and Heimann, 1999). Second, our GISS GCM simulations for 2050 and 2100 do not show substantial decreases in tropical terrestrial precipitation relative to the present-day.

Figure 3 shows the model calculated summertime surface ozone for present-day and the anomaly due to climate and $\mathrm{CO}_{2}$-driven land cover change over the period 2000-2100. With the vegetation changes we simulated, we found significant decreases in surface ozone over large areas of the northern mid-latitudes, particularly in Eurasia where ozone decreases locally by up to $5 \mathrm{ppb}$ at 2050 and $10 \mathrm{ppb}$ at 2100 . This appears to be largely driven by the increase in ozone dry deposition on denser and more broadleaf vegetation (Fig. 2). For areas with decreasing surface ozone, the ozone dry deposition velocities are generally calculated to increase by 10 $50 \%$ by 2100 , with the strongest increases found over northern mid-latitudes. General increases in LAI are calculated for most areas globally, with the largest increases (by up to
$200 \%$ by 2100) found for boreal forests. The increases in LAI reflect increasing vegetation density in a warmer and wetter climate with higher atmospheric $\mathrm{CO}_{2}$ abundance. The increase in LAI is a major factor enhancing the ozone dry deposition (Gao and Wesely, 1995; Ganzeveld et al., 2010; Wang et al., 1998). In addition to affecting the ozone dry deposition, the shifts from needle leaf trees to broad leaf trees and the increases in LAI also enhance the biogenic emissions of NMVOCs. Increases in isoprene emissions in remote areas also contribute to the ozone decrease. Many remote parts of Eurasia have relatively low $\mathrm{NO}_{\mathrm{x}}$ abundance, hence increasing isoprene emissions lead to a decrease in surface ozone levels (Weidinmyer et al., 2006; Wu et al, 2007, 2008). This is in contrast to the Northeastern US where surface ozone increases with stronger isoprene emissions due to the relatively high ambient $\mathrm{NO}_{\mathrm{x}}$ levels. The dependence of ozone's sensitivity to isoprene emissions on $\mathrm{NO}_{\mathrm{x}}$ levels will be further discussed in the final section. The increase in surface ozone over the southern Sahara is driven by increases in soil $\mathrm{NO}_{\mathrm{x}}$ emissions associated with increases in vegetation. Since the southern Sahara is dominated by desert lands with very low soil $\mathrm{NO}_{\mathrm{x}}$ emissions (Yienger and Levy, 1995), increasing vegetation coverage there leads to increases in soil $\mathrm{NO}_{\mathrm{x}}$ emissions by more than $20 \%$ over the period of $2000-$ 2100. On the other hand, the global soil $\mathrm{NO}_{\mathrm{x}}$ emission is calculated to decrease by $3 \%$ due to vegetation change between 

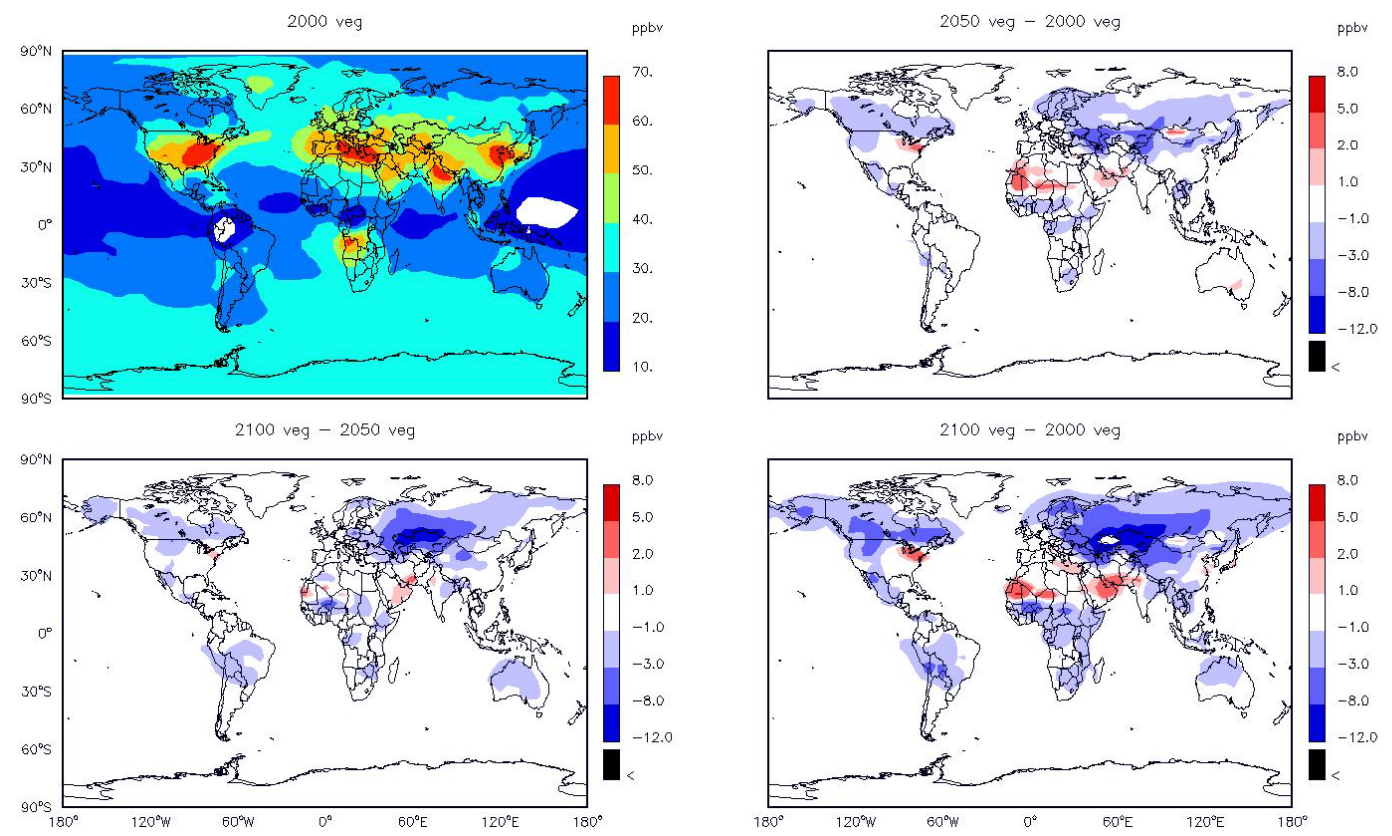

Fig. 3. Model simulated (upper left) surface ozone for present-day and the changes in surface ozone due to vegetation change driven by climate change and increasing atmospheric $\mathrm{CO}_{2}$ abundance between (upper right) 2050 and2000, (lower left) 2100 and 2050 , and (lower right) 2100 and 2000. Ozone values based on summertime (JJA) afternoon (13-17 local time) averages. Color scales are saturated at maximum and minimum values.

2100 and 2000, reflecting the significant increases in LAI which enhance the canopy reduction of $\mathrm{NO}_{\mathrm{x}}$ emissions. Similar trends are found for other seasons, although the perturbations have smaller magnitude than that in summer.

The 2000-2100 change in vegetation driven by climate change has only minor effects on the global burden of tropospheric ozone (less than 1\%; Table 1). Significant perturbations to tropospheric $\mathrm{OH}$ are calculated, with the global annual mean tropospheric $\mathrm{OH}$ decreases by $2 \%$ and $4 \%$ by 2050 and 2100 respectively (Table 1), which is largely driven by the increases in isoprene emissions. However, this may not be a robust result considering that recent field and mechanistic studies find no $\mathrm{OH}$ depletion from isoprene chemistry (Lelieveld et al., 2008; Stavrakou et al., 2010).

The perturbations to surface ozone due to changes in land cover calculated in this study are very different from those reported in Sanderson et al. (2003). The factors that could contribute to this discrepancy include: (1) Our climate model simulations do not show the dieback of Amazon forests as found in Sanderson et al. (2003), and (2) there are large uncertainties associated with isoprene chemistry and in particular the treatment of isoprene nitrates, especially isoprene nitrate, could be different in different models (Giacopelli et al., 2005; Horowitz et al., 2007; Paulot et al., 2009). The response of ozone to isoprene emissions is highly sensitive to whether isoprene nitrates represent a terminal or temporary sink for $\mathrm{NO}_{\mathrm{x}}$ (Horowitz et al., 2007; Wu et al., 2007). In our model, isoprene nitrate represents a terminal sink, as shown in Giacopelli et al. (2005). Therefore, except for areas with abundant $\mathrm{NO}_{\mathrm{x}}$ available such as northeastern United States, the increases in isoprene emissions tend to reduce ozone levels because of (1) sequestration of $\mathrm{NO}_{\mathrm{x}}$ as isoprene nitrates (Wu et al., 2007), and (2) direct ozonolysis of isoprene (Fiore et al., 2005).

Figure 4 shows the effects of land cover change on the atmospheric concentrations of SOA. Our model simulations show that oxidation products from isoprene and monoterpene are dominant contributors to SOA production, accounting for about $70 \%$ and $20 \%$ of the total atmospheric SOA burden respectively. We find that the summertime SOA could increase by more than $0.5 \mu \mathrm{g} \mathrm{m}^{-3}$ by 2100 over large areas in Eurasia, reflecting the strong increases in biogenic NMVOC emissions in that region, particularly from isoprene. The annual mean surface SOA concentration doubles by 2100 for this region. Some decreases in surface SOA concentrations are calculated for two relatively small regions in northeastern China and west Russia respectively. These decreases are due to decreases in monoterpenes emissions associated with the projected retreat in conifer forests (Fig. 2). We find that the global burden of SOA increases by $10 \%$ to $20 \%$ by 2050 and 2100 , respectively (Table 1 ). 

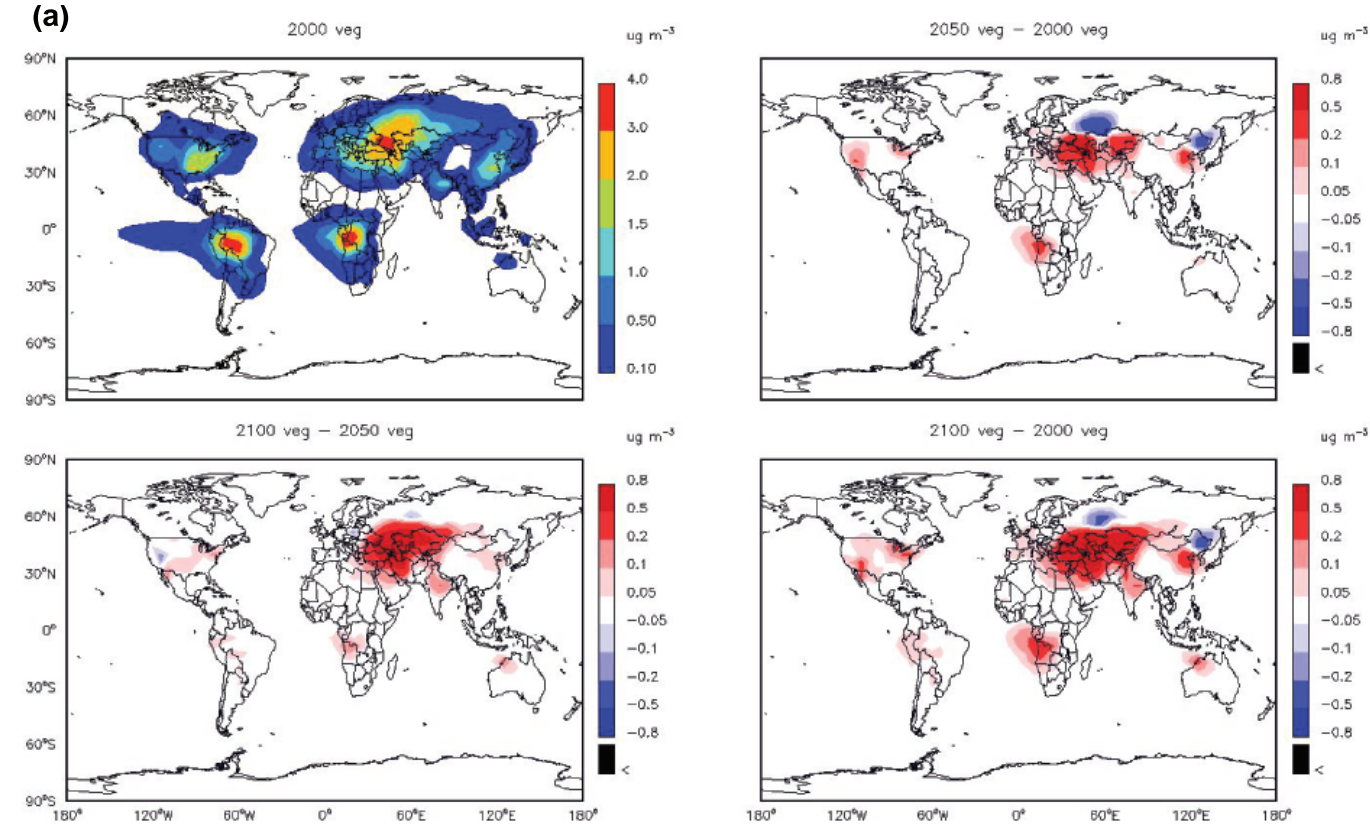

Fig. 4a. Same as Fig. 3 but for secondary organic aerosols. Color scales saturate.
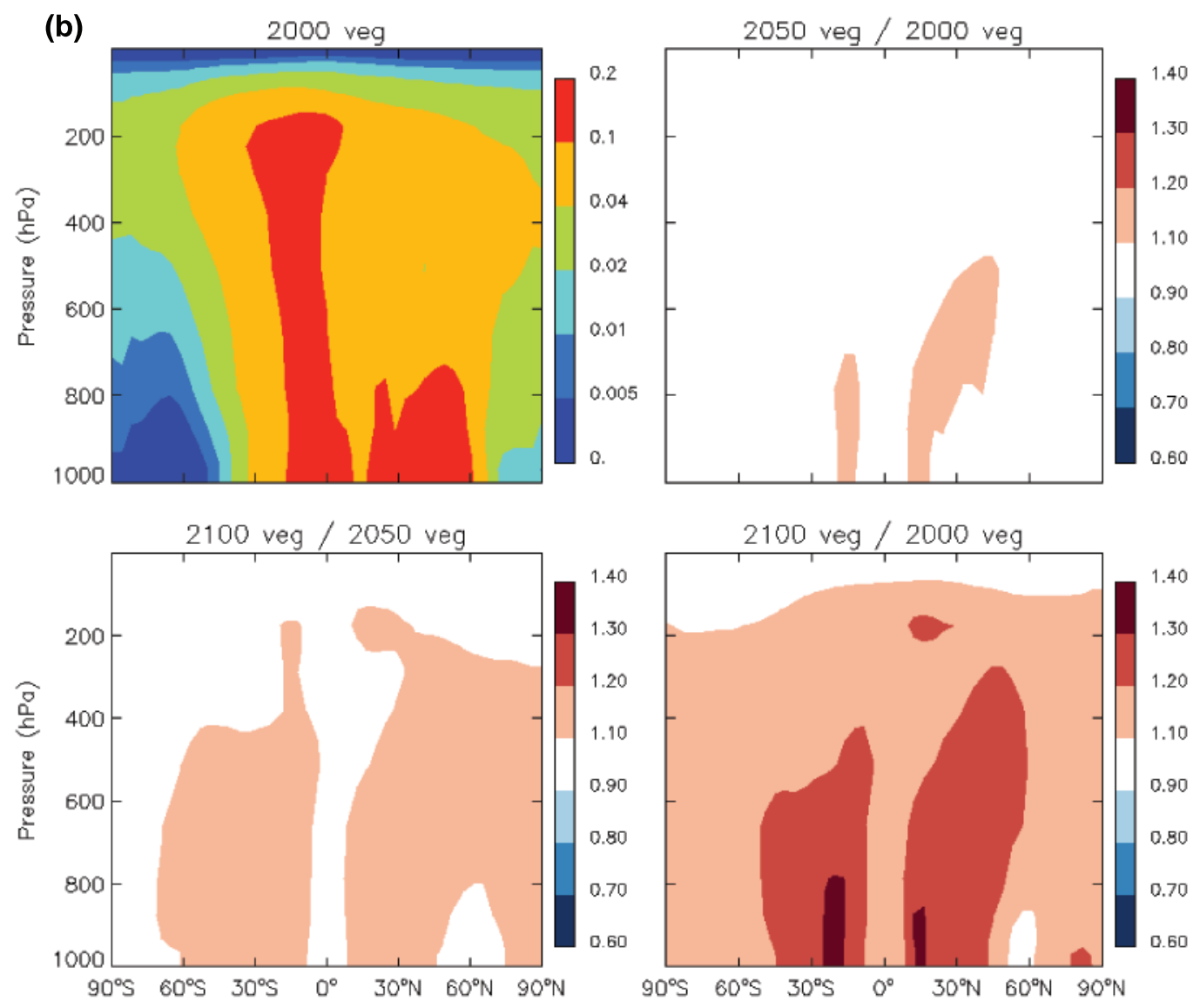

Fig. 4b. Same as Fig. 4a but for zonal mean. 


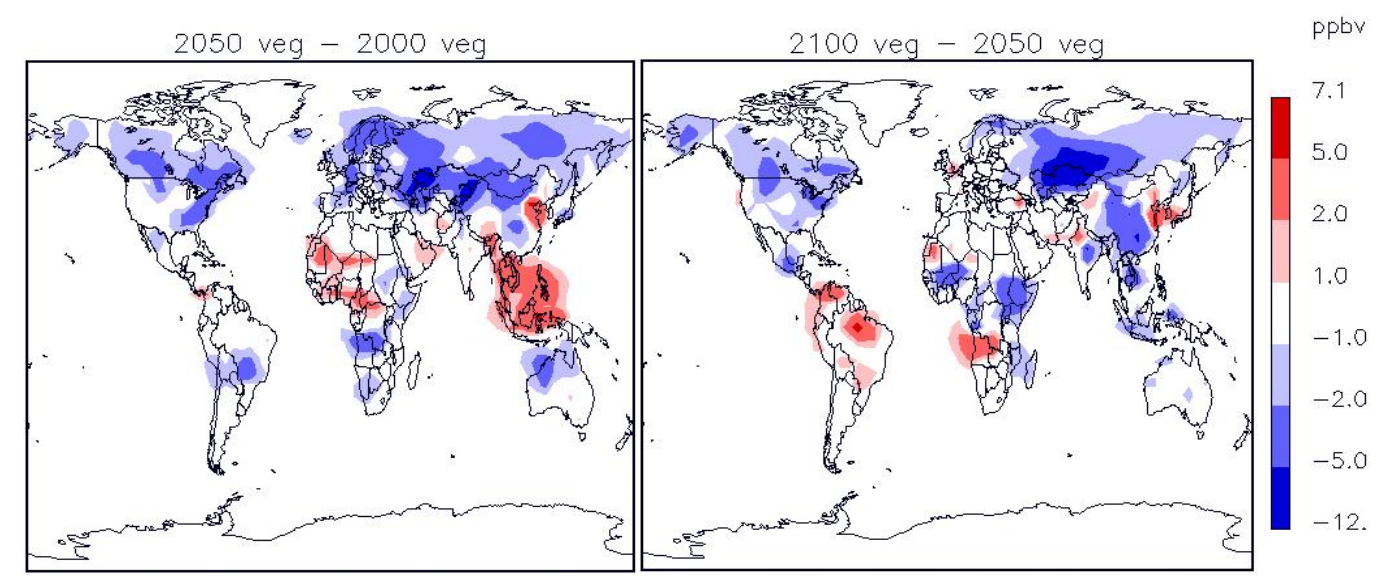

Fig. 5. Changes in June-August surface ozone due to vegetation change driven by combined effects (changes in climate, $\mathrm{CO}_{2}$ abundance and agricultural land use) for the periods of 2000-2050 (left) and 2050-2100 (right). Color scales saturate.

\subsection{Combined impacts from agricultural land use change and climate-driven vegetation change}

We followed the IPCC A1B scenario for changes in anthropogenic land use (IPCC 2001; MNP, 2006). Over the period 2000-2050, the agricultural land use is projected to decrease over some regions including East Asia but increases over some others such as eastern United States, South Asia, and Central Africa, which is largely driven by changes in population, economic developments, energy supply and demand (e.g., energy crops) (MNP, 2006). Isoprene emissions generally decrease with increasing agricultural land use since crops are of the lowest isoprene emission rates among all the plant function types (Guenther et al., 2006). The decreases in isoprene emissions associated with anthropogenic land use change over east United States, South Asia and Central Africa more than compensate the increases in isoprene emissions associated with climate- and $\mathrm{CO}_{2}$-driven vegetation change (as shown in Sect. 3.1). As a consequence, the global isoprene emissions for 2050 decrease by $5 \%$ compared to 2000 (Table 1). Associated with the 2000-2050 agricultural land use changes over South Asia and Central Africa, we find significant increases in surface ozone of up to $5 \mathrm{ppb}$ in those regions (Fig. 5), which appears driven by decreases in ozone deposition and isoprene emissions. In contrast, over east United States where there is relatively high $\mathrm{NO}_{\mathrm{x}}$ abundance, surface ozone decreases with decreasing isoprene emissions. As discussed in Sect. 3.1, the response of ozone to biogenic isoprene emissions is highly sensitive to the chemical mechanism of isoprene oxidation used in the model.

The projected trends of agricultural land use for South Asia and Central Africa reverse after 2050; i.e. the total amount of land under cultivation decreases between 2050 and 2100 , reflecting the projected human population maximum around 2050 (Nakicenovic and Swart, 2000). As a consequence, our model simulations over these regions show increasing isoprene emissions and decreasing surface ozone for the 2050-2100 period (Fig. 5). Significant increases in agricultural land use are projected between 2050 and 2100 over the Amazon region where the isoprene would decrease leading to increasing surface ozone. Global total annual biogenic emissions are calculated to increase in 2100 compared to year 2000 , with isoprene emissions up by $8 \%$ and mototerpenes up by $12 \%$.

The changes in agricultural land use also have large effects on SOA. We find that when the agricultural land use change is accounted for, the global SOA burden in 2100 remains almost the same as 2000 (Table 1), in contrast to the large increase of $20 \%$ when only climate change and increasing $\mathrm{CO}_{2}$ abundance are considered (as shown in Sect. 3.1). This implies that the projected expansion in agricultural land use between 2000 and 2100 lowers the global SOA burden by about $20 \%$, which compensates for the effects of climate- and $\mathrm{CO}_{2}$-driven changes in vegetation cover and composition. Heald et al. (2008) calculated a somewhat smaller $(-14 \%)$ perturbation from changes in the anthropogenic land use by 2100, which could reflect difference in the models used and also scenarios assumed for future changes in anthropogenic land use. The little change in SOA burden from 2000 to 2100 despite the significant increases in biogenic emissions (Table 1) also reflects the changes in seasonality of biogenic emissions. Increases in cropland imply that the biogenic emissions would be shifted more to the growth season (such as summer) when biogenic VOCs have the shortest atmospheric lifetime.

Figure 6 shows the model simulated changes in surface SOA concentrations due to changes in land use and land cover driven by the combined effects. We can see that the SOA increases by up to $1 \mu \mathrm{g} \mathrm{m}^{-3}$ by 2100 over the Eurasia region reflecting the changes in biogenic emissions of 


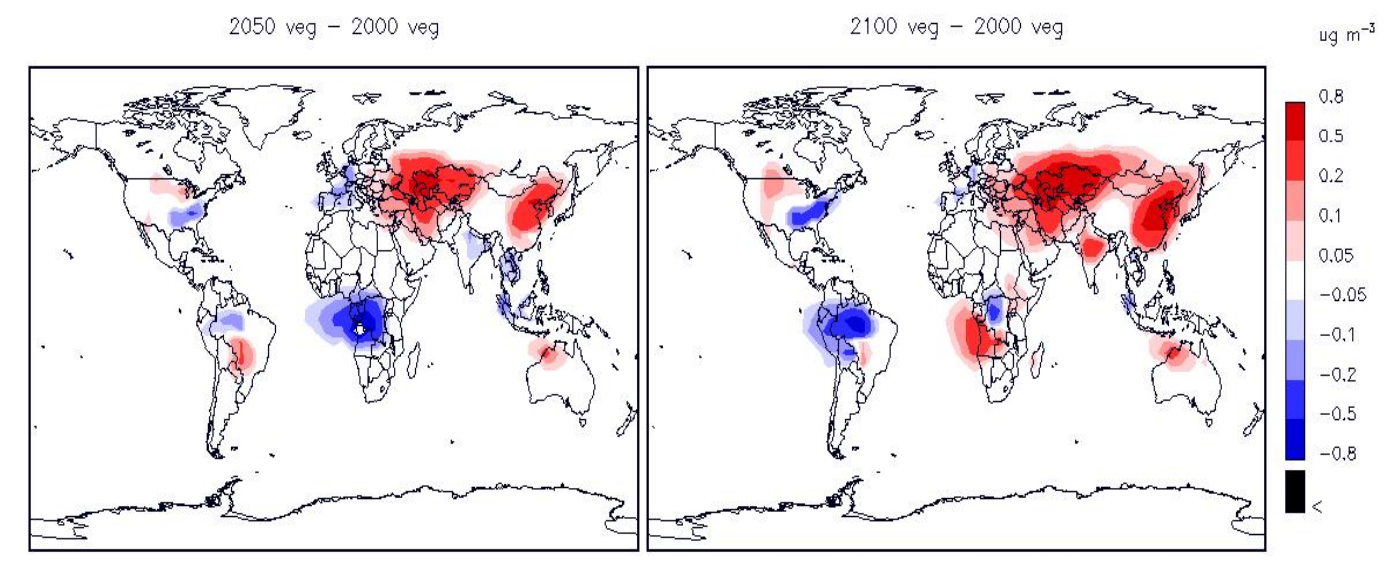

Fig. 6. Same as Fig. 5 but for surface secondary organic aerosols. Color scales saturate.

NMVOCs, in particular isoprene. Decreases in SOA concentrations, by up to $0.5 \mu \mathrm{g} \mathrm{m}^{-3}$ are calculated over the Amazon forest and eastern United States, which is driven by reduced biogenic isoprene and monoterpene emissions associated with increasing agricultural land use.

\section{Discussion and conclusions}

We investigated the potential effects on atmospheric chemistry and air quality from 2000-2100 changes in land use and land cover driven by climate change, increasing atmospheric $\mathrm{CO}_{2}$ abundance, and agricultural land use change. To accomplish this, we performed an offline coupling of a general circulation model (GISS GCM 3) with a global chemical transport model (GEOS-Chem CTM) and a dynamic global vegetation model (LPJ DGVM).

In the absence of future anthropogenic land use change, the generally warmer and wetter future climate simulated by the GISS GCM leads to changes in the composition of forests, chiefly in the northern temperate and boreal latitudes, which in turn lead to decreases in summer afternoon surface ozone by up to $10 \mathrm{ppb}$ over large areas over the northern mid-latitudes. This is largely driven by the enhanced ozone dry deposition associated with the transition from needleleaf forests to those dominated by broadleaf trees and by increases in LAI associated with $\mathrm{CO}_{2}$ fertilization. Climatedriven land cover changes also lead to general increases in isoprene emissions by forests. Global annual total isoprene emissions are calculated to increase by $10 \%$ in 2050 and $25 \%$ in 2100 compared to 2000 conditions.

Increasing isoprene emissions contribute to further decreases of surface ozone in remote areas but also lead to increases in surface ozone over polluted regions such as northeastern United States. Ozone production is generally $\mathrm{NO}_{\mathrm{x}}$ limited in remote areas and higher isoprene emissions enhances both direct ozone-isoprene reactions and the seques- tration of $\mathrm{NO}_{\mathrm{x}}$ as isoprene nitrates (Fiore et al., 2005; Weidinmyer et al., 2006; Wu et al., 2007). However, there are large uncertainties associated with our understanding on and model treatment of isoprene nitrate chemistry, which can affect the sensitivity of ozone responses to isoprene emissions (Giacopelli et al., 2005; Horowitz et al., 2007; Jacob and Winner, 2009; Paulot et al., 2009; Wu et al., 2008a).

We note again that the possible $\mathrm{CO}_{2}$ inhabitation effect on isoprene emissions is not accounted here. Heald et al. (2009) estimated that this inhabitation effect could imply a $30 \%$ decrease in global isoprene emissions by 2100 following the A1B scenario, but the magnitude of the inhibition is uncertain (Centritto et al., 2004; Possell et al., 2005). In addition, assigning emission factors to specific PFTs rather than plant species, as implemented in the MEGAN scheme, could introduce uncertainties in the projected isoprene emissions.

Our results also show that changes in vegetation cover over the period 2000-2100 would lead to a general increase in SOA concentrations, driven by increases in biogenic VOC emissions. The global SOA burden increases by $10 \%$ to $20 \%$ by 2050 and 2100 respectively. The increase in global SOA burden has important implications for direct radiative forcing (e.g., Chung and Seinfeld, 2002; Liao et al., 2004). Increasing SOA concentrations also significantly affect the particulate matter (PM) air quality with the largest perturbations found over the Eurasia, where locally, summertime SOA concentrations in surface air are calculated to increase by as much as $1 \mu \mathrm{g} \mathrm{m}^{-3}$ by 2100 . When we used a scenario of future anthropogenic land use change, we found compensating effects on isoprene emissions and SOA resulting in little net change in global SOA burden over the 2000-2100 period.

There are many sources of uncertainty in the projected responses of future atmospheric composition to the changes in land use and land cover. The future changes in anthropogenic land use is strongly affected by multiple factors (such as population and economic growth, development in 
renewable energy and new technology, policy regulations) which all show large spatial and temporal variability. The simulation of climate-driven changes in land cover only resolves PFTs but not specific vegetation species, introducing additional sources of uncertainty.

The evolution of atmospheric chemistry and air quality in the future is affected by many factors in the context of global change, including the changes in anthropogenic emissions, climate, as well as land use and land cover. Previous studies (e.g., Johnson et al., 1999; Stevenson et al., 2000, 2006; Hauglustaine et al., 2005; Brasseur et al., 2006; Racherla and Adams, 2006; Wu et al., 2008ab) have shown significant impacts on natural emissions, deposition, and atmospheric chemistry directly driven by changes in meteorology (such as temperature, humidity, solar radiation) associated with climate change. In order to separate the effects due to changes in land use/land cover from those due to changes in anthropogenic emissions and climate, we have purposefully used the present-day anthropogenic emissions and meteorology for atmospheric chemistry simulations in this study.

Our study does not account for possible changes in vegetation caused by changes in the frequency and intensity of wildfires, which may be substantially affected by climate change (Flannigan and Harrington, 1988; McKenzie, et al., 2004; Stocks et al., 1998; Swetnam, 1993). Additionally, changes in tropospheric ozone and SOA in response to land use and land cover change can further affect climate through radiative forcing, but this feedback is not considered in our study. Previous studies also indicated that changes in the chemical composition of the atmosphere such as increasing ozone concentrations can affect vegetation and thus the terrestrial carbon cycle (e.g., Felzer et al., 2004) and produce an indirect radiative forcing effect (Sitch et al., 2007); these effects were also not considered in this study. Finally, the changes in anthropogenic emissions could affect the responses of atmospheric composition to vegetation change. For example, increases in anthropogenic $\mathrm{NO}_{\mathrm{x}}$ emissions could either increase the sensitivity of ozone to biogenic VOC emissions or even switch the ozone production from $\mathrm{NO}_{\mathrm{x}}$-limited regime to VOC-limited regime.The significant perturbations to ozone and aerosol air quality associated with future land use and land cover change, as demonstrated by our results, imply that the effects from vegetation change driven by both climate change and anthropogenic land use need to be considered in air quality management and planning at time scales of decades or longer. It also indicates that better understanding and quantification of the complicated interactions and feedbacks between climate and atmospheric chemistry is greatly needed in the context of global change research.
Acknowledgements. This work was supported by the US EPA STAR program (Grant R83428601) and the National Aeronautics and Space Administration (NASA-MAP Grant NNG06GB48G). We thank the editor and two reviewers for their constructive comments.

Edited by: L. Ganzeveld

\section{References}

Alexander, B., Park, R .J., Jacob D. J., Li, Q. B., Yantosca, R. M., Savarino, J., Lee, C. C. W., and Thiemens, M. H.: Sulfate formation in sea-salt aerosols: Constraints from oxygen isotopes, J. Geophys. Res., 110, D10307, doi:10.1029/2004JD005659, 2005.

Arneth, A., Niinemets, Ü., Pressley, S., Bck, J., Hari, P., Karl, T., Noe, S., Prentice, I. C., Sera, D., Hickler, T., Wolf, A., and Smith, B.: Process-based estimates of terrestrial ecosystem isoprene emissions: incorporating the effects of a direct $\mathrm{CO}_{2}$-isoprene interaction, Atmos. Chem. Phys., 7, 31-53, doi:10.5194/acp-731-2007, 2007.

Bachelet, D., Neilson, R. P., Lenihan, J. M., and Drapek, R. J.: Climate change effects on the vegetation distribution and carbon budget in the United States, Ecosystems, 4, 164-185, 2001.

Bachelet, D., R. P. Neilson, T., Hickler, R. J., Drapek, J. M., Lenihan, M. T., Sykes, B., Smith, S., Sitch, and Thonicke, K.: Simulating past and future dynamics of natural ecosystems in the United States, Global Biogeochem. Cy., 17, 1045, doi:1029/2001GB001508, 2003.

Bey, I., Jacob, D. J., Yantosca R. M., Logan, J. A., Field, B. D., Fiore, A. M., Li, Q., Liu, H., Mickley, L. J., and Schultz, M.: Global modeling of tropospheric chemistry with assimilated meteorology: Model description and evaluation, J. Geophys. Res., 106, 23073-23096, 2001.

Brasseur, G. P., Schultz, M., Granier, C., Saunois, M., Diehl, T., Botzet, M., Roeckner, E., and Walters, S.: Impact of climate change on the future chemical composition of the global troposphere, J. Clim., 19, 3932-3951, doi:10.1175/JCLI3832.1, 2006.

Centritto, M., Nascetti, P., Petrilli, L., Raschi, A., and Loreto, F.: Profiles of isoprene emission and photosynthetic parameters in hybrid poplars exposed to free-air $\mathrm{CO}_{2}$ enrichment, Plant Cell Environ, 27, 403-412, 2004.

Chung, S. H. and Seinfeld, J. H.: Global distribution and climate forcing of carbonaceous aerosols, J. Geophys. Res., 107, 4407, doi:10.1029/2001JD001397, 2002.

Cox, P. M., Betts, R. A., Jones, C. D., Spall, S. A., and Totterdell, I. J.: Acceleration of global warming due to carbon-cycle feedbacks in a coupled climate model, Nature, 408, 184-187, 2000.

Cox, P. M., Betts, R. A., Collins, M., Harris, P. P., Huntingford, C., and Jones, C. D.: Amazonian forest dieback under climatecarbon cycle projections for the 21st century, Theor. Appl. Climatol., 78, 137-156, 2004.

Cramer, W., Bondeau, A., Woodward, F. I., Prentice, I. C., Betts, R. A., Brovkin, V., Cox, P. M., Fisher, V., Foley, J. A., Friend, A. D., Kucharik, C., Lomas, M. R., Ramankutty, N., Sitch, S., Smith, B., White, A., and Young-Molling C.: Global response of terrestrial ecosystem structure and function to $\mathrm{CO}_{2}$ and climate change: results from six dynamic global vegetation models, Glob. Change. Biol., 7, 357-373, 2001. 
Cramer, W., A. Bondeau, S. Schaphoff, W. Lucht, B. Smith, and S. Sitch, Tropical forests and the global carbon cycle: impacts of atmospheric carbon dioxide, climate change, and rate of deforestation, Phil. Trans. R. Soc. Lond. B, 359, 331-343, 2004.

DeLucia, E. H., Moore, D. J., and Norby, R. J.: Contrasting responses of forest ecosystems to rising atmospheric $\mathrm{CO}_{2}$ : implications for the global C cycle, Global Biogeochem. Cy., 19, GB3006, doi:10.1029/2004GB002346, 2005.

Fairlie, T. D., Jacob, D. J., and Park, R. J.: The impact of transpacific transport of mineral dust in the United States, Atmos. Environ., 41, 1251-1266, 2007.

FAO: Global Forest Resources Assessment, Rome, http://www.fao. org/docrep/004/y1997e/y1997e00.HTM, last access: 13 February 2012, 2000.

Felzer, B., Kicklighter, D., Melillo, J., Wang, C., Zhuang, Q., and Prinn, R.: Effects of ozone on net primary production and carbon sequestration in the conterminous United States using a biogeochemistry model, Tellus B, 56, 230-248, doi:10.1111/j.16000889.2004.00097.x, 2004.

Fiore, A. M., Jacob, D. J., Field, B. D., Streets, D. G., Fernandes, S. D., and Jang, C.: Linking ozone pollution and climate change: The case for controlling methane, Geophys. Res. Lett., 29, 1919, doi:10.1029/2002GL015601, 2002a.

Fiore, A. M., Jacob, D. J., Bey, I., Yantosca, R. M., Field, B. D., Fusco, A. C., and Wilkinson, J. G.: Background ozone over the United States in summer: Origin, trend, and contribution to pollution episodes, J. Geophys. Res., 107, 4275, doi:10.1029/2001JD000982, 2002b.

Fiore, A. M., Jacob, D. J., Mathur, R., and Martin, R. V.: Application of empirical orthogonal functions to evaluate ozone simulations with regional and global models, J. Geophys. Res., 108, 4431, doi:10.1029/2002JD003151, 2003.

Fiore, A. M., Horowitz, L. W., Purves, D. W., Levy II, H., Evans, M. J., Wang, Y., Li, Q., and Yantosca, R. M.: Evaluating the contribution of changes in isoprene emissions to surface ozone trends over the eastern United States, J. Geophys. Res., 110, D12303, doi:10.1029/2004JD005485, 2005.

Flannigan, M. D. and Harrington, J. B.: A study of the relation of meteorological variables to monthly provincial area burned by wildfire in Canada (1953-80), J. Appl. Meteorol., 27, 441-452, 1988.

Ganzeveld, L. and Lelieveld, J.: Impact of Amazonian deforestation on atmospheric chemistry, Geophys. Res. Lett., 31, L06105, doi:10.1029/2003GL019205, 2004.

Ganzeveld, L., Bouwman, L., Stehfest, E., van Vuuren, D. P., Eickhout, B., and Lelieveld, J.: Impact of future land use and land cover changes on atmospheric chemistry-climate interactions, J. Geophys. Res., 115, D23301, doi:10.1029/2010JD014041, 2010.

Gao, W. and Wesely, M. L.: Modeling gaseous dry deposition over regional scales with satellite observations, 1. Model development, Atmos. Environ, 29, 727-737, 1995.

Giacopelli, P., Ford, K., Espada, C., and Shepson, P. B.: Comparison of the measured and simulated isoprene nitrate distributions above a forest canopy, J. Geophys. Res., 110, D01304, doi:10.1029/2004JD005123, 2005.

Guenther, A., Hewitt, C. N., Erickson, D., Fall, R., Geron, C., Graedel, T., Harley, P., Klinger, L., Lerdau, M., McKay, W., Pierce, T., Scholes, B., Steinbrecher, R., Tallamraju, R., Taylor, J., and Zimmerman, P.: A global model of natural volatile or- ganic compound emissions, J. Geophys. Res., 100, 8873-8892, 1995.

Guenther, A., Karl, T., Harley, P., Wiedinmyer, C., Palmer, P. I., and Geron, C.: Estimates of global terrestrial isoprene emissions using MEGAN (Model of Emissions of Gases and Aerosols from Nature), Atmos. Chem. Phys., 6, 3181-3210, doi:10.5194/acp-63181-2006, 2006.

Hauglustaine, D. A., Lathiére J., Szopa, S., and Folberth, G. A.: Future tropospheric ozone simulated with a climatechemistry-biosphere model, Geophys. Res. Lett., 32, L24807, doi:10.1029/2005GL024031, 2005.

Heald, C. L., Henze, D. K., Horowitz, L. W., Feddema, J., Lamarque, J. F., Guenther, A., Hess, P. G., Vitt, F., Seinfeld, J. H., Goldstein, A. H., and Fung, I.: Predicted change in global secondary organic aerosol concentrations in response to future climate, emissions, and land use change, J. Geophys. Res., 113, D05211, doi:10.1029/2007JD009092, 2008.

Heald, C. L., Wilkinson, M. J., Monson, R. K., Alo, C. A., Wang, G., and Guenther, A.: Response of isoprene emission to ambient $\mathrm{CO}_{2}$ changes and implications for global budgets, Glob. Change Biol., 15, 4, 1127-1140, 2009.

Henze, D. K. and Seinfield, J. H.: Global secondary organic aerosol from isoprene oxidation, Geophys. Res. Lett., 33, L09812, doi:10.1029/2006GL025976, 2006.

Henze, D. K., Seinfeld, J. H., Ng, N. L., Kroll, J. H., Fu, T.-M., Jacob, D. J., and Heald, C. L.: Global modeling of secondary organic aerosol formation from aromatic hydrocarbons: highvs. low-yield pathways, Atmos. Chem. Phys., 8, 2405-2420, doi:10.5194/acp-8-2405-2008, 2008.

Hogrefe, C., Lynn, B., Civerolo, K., Ku, J.-Y., Rosenthal, J., Rosenzweig, C., Goldberg, R., Gaffin, S., Knowlton, K., and Kinney, P. L.: Simulating changes in regional air pollution over the eastern United States due to changes in global and regional climate and emissions, J. Geophys. Res., 109, D22301, doi:10.1029/2004JD004690, 2004.

Houghton, R. A., Skole, D. L., Nobre, C. A., Hackler, J. L., Lawrence, K. T., and Chomentowski, W. H.: Annual fluxes of carbon from deforestation and regrowth in the Brazilian Amazon, Nature, 403, 301-304, 2000.

Houweling, S., Dentener, F., and Lelieveld, J.: The impact of nonmethane hydrocarbon compounds on tropospheric photochemistry, J. Geophys. Res., 103, 10673-10696, 1998.

Hudman, R. C., Jacob, D. J., Turquety, S., Leibensperger, E. M., Murray, L. T., Wu, S., Gilliland, A. B., Avery, M., Bertram, T. H., Brune, W., Cohen, R. C., Dibb, J. E., Flocke, F. M., Fried, A., Holloway, J. S., Neuman, J. A., Orville, R., Perring, A., Ren, X., Sachse, G. W., Singh, H. B., Swanson, A., and Wooldridge, P. J.: Surface and lightning sources of nitrogen oxides over the United States: magnitudes, chemical evolution, and outflow, J. Geophys. Res., 112, D12S05, doi:10.1029/2006JD007912, 2007.

IMAGE-Team: The IMAGE 2.2 implementation of the SRES scenarios: A comprehensive analysis of emissions, climate change and impacts in the 21st century, RIVM CD-ROM publication 481508018, Natl. Inst. for Public Health \& the Environment, Bilthoven, 2001.

IPCC: Climate Change 2001: The Scientific Basis, contribution of Working Group I to the Third Assessment Report of the Intergovernmental Panel on Climate Change, edited by: Houghton, J. T., Ding, Y., Griggs, D. J., Noguer, M., van der, P. J. Linden, 
Dai, X., Maskell, K., and Johnson, C. A., Cambridge University Press, Cambridge, United Kingdom and New York, NY, USA, 881 pp., 2001.

IPCC: Climate Change 2007: The Physical Science Basis, contribution of Working Group I to the Fourth Assessment Report of the Intergovernmental Panel on Climate Change, edited by Solomon, S. S., Qin, D., Manning, M., Chen, Z., Marquis, M., Averyt, K. B., Tignor, M., and Miller, H. L., Cambridge Univ. Press, Cambridge, United Kingdom and New York, NY, USA, 996 pp., 2007.

Jacob, D. J. and Winner, D. A.: Effect of climate change on air quality, Atmos. Environ., 43, 51-63, 2009.

Jiang, X., Wiedinmyer, C., Chen, F., Yang, Z.-L., and Lo, J. C.F.: Predicted impacts of climate and land use change on surface ozone in the Houston, Texas, area, J. Geophys. Res., 113, D20312, doi:10.1029/2008JD009820, 2008.

Johnson, C. E., Collins, W. J., Stevenson, D. S., and Derwent, R. G.: The relative roles of climate and emissions changes on future oxidant concentrations, J. Geophys. Res., 104, 18631-18645, doi:10.1029/1999JD900204, 1999.

Kaplan, J. O., Prentice, I. C., Knorr, W., and Valdes, P. J.: Modeling the dynamics of terrestrial carbon storage since the Last Glacial Maximum, Geophys. Res. Lett., 29, 2074, doi:10.1029/2002GL015230, 2002.

Kaplan, J. O., Bigelow, N. H., Prentice, I. Colin, Harrison, Sandy P., Bartlein, Patrick J., Christensen, T. R., Cramer, W., Matveyeva, N. V., McGuire, A. D., Murray, D. F., Razzhivin, V. Y., Smith, B., Walker, Donald A., Anderson, P. M., Andreev, A. A., Brubaker, L. B., Edwards, M. E., and Lozhkin, A. V. Climate change and Arctic ecosystems: 2. Modeling, paleodata-model comparsons, and future projections, J. Geophys. Res., 108, 8171, doi:1029/2002/JD002559, 2003.

Kleidon, A. and Heimann, M.: Assessing the role of deep rooted vegetation in the climate system with model simulations: Mechanism, comparison to observations and implications for Amazonian deforestation, Climate Dyn., 16, 183-199, 1999.

Kroll, J. H., Ng, N. L., Murphy, S. M., Flagan, R. C., and Seinfeld, J. H.: Secondary organic aerosol formation from isoprene photooxidation, Environ. Sci. Technol., 40, 1869-1877, doi:10.1021/es0524301, 2006.

Lathière, J., Hauglustaine, D. A., Friend, A. D., De NobletDucoudr, N., Viovy, N., and Folberth, G. A.: Impact of climate variability and land use changes on global biogenic volatile organic compound emissions, Atmos. Chem. Phys., 6, 2129-2146, doi:10.5194/acp-6-2129-2006, 2006.

Lelieveld, J., Butler, T. M., Crowley, J. N., Dillon, T. J., Fischer, H., Ganzeveld, L., Harder, H., Lawrence, M. G., Martinez, M., Taraborrelli, D., and Williams, J.: Atmospheric oxidation capacity sustained by a tropical forest, Nature, 452, 737-740, 2008.

Levy, P. E., Cannell, M. G. R., and Friend, A. D.: Modelling the impact of future changes in climate, $\mathrm{CO}_{2}$ concentration and land use on natural ecosystems and the terrestrial carbon sink, Global Environ. Chang., 14, 21-30, 2004.

Liao, H., Seinfeld, J. H., Adams, P. J., an Mickleyd, L. J.: Global radiative forcing of coupled tropospheric ozone and aerosols in a unified general circulation model, J. Geophys. Res., 109, D16207, doi:10.1029/2003JD004456, 2004.

Liao, H., Henze, D. K., Seinfeld, J. H., Wu, S., and Mickley, L. J.: Biogenic secondary organic aerosol over the United States:
Comparison of climatological simulations with observations, J. Geophys. Res., 112, D06201, doi:10.1029/2006JD007813, 2007.

Logan, J. A.: An analysis of ozonesonde data for the troposphere: Recommendations for testing 3-D models and development of a gridded climatology for tropospheric ozone, J. Geophys. Res., 104, 16115-16149, 1999.

McKenzie, D., Gedalof, Z., Peterson, D., and Mote, P.: Climatic change, wildfire, and conservation, Conserv. Biol., 18, 890-902, 2004.

McLinden, C. A., Olsen, S. C., Hannegan, B., Wild, O., Prather, M. J., and Sundet, J.: Stratospheric ozone in 3-D models: A simple chemistry and the cross-tropopause flux, J. Geophys. Res., 105, 14653-14665, 2000.

Meszaros, R., Szinyei, D., Vincze, C., Lagzi, I., Turanyi, T., Haszpra, L., and Tomlin, A. S.: Effects of the soil wetness state on the stomatal ozone fluxes over Hungary, Int. J. Environ Pollut., 36, 180-194, doi:10.1504/IJEP.2009.021825, 2009.

MNP: Integrated modelling of global environmental change, an overview of IMAGE 2.4., edited by: Bouwman, A. F., Kram, T., and Klein Goldewijk, K., Netherlands Environmental Assessment Agency (MNP), Bilthoven, The Netherlands, 2006.

Nakicenovic, N. and Swart, R. (Eds.): Special Report on Emissions Scenarios, 570 pp., Cambridge Univ. Press, New York, USA, 2000.

Nowak, R. S., Ellsworth, D. S., and Smith, S. D.: Functional responses of plants to elevated atmospheric $\mathrm{CO}_{2}-$ do photosynthetic and productivity data from FACE experiments support early predictions?, New Phytol., 162, 253-280, 2004.

Olson, J. S.: World Ecosystems (WE1.4). Digital Raster Data on a 10-minute Cartesian Orthonormal Geodetic $1080 \times 2160$ grid, in: Global Ecosystems Database, Version 2.0. Boulder, CO: National Geophysical Data Center, 1992.

Park, R. J., Jacob, D. J., Field, B. D., Yantosca, R. M., and Chin, M.: Natural and transboundary pollution influences on sulfate-nitrateammonium aerosols in the United States: Implications for policy, J. Geophys. Res., 109, D15204, doi:10.1029/2003JD004473, 2004.

Park, R. J., Jacob, D. J., Kumar, N., and Yantosca, R. M.: Regional visibility statistics in the United States: Natural and transboundary pollution influences, and implications for the Regional Haze Rule, Atmos. Environ., 40, 5405-5423, 2006.

Paulot, F., Crounse, J. D., Kjaergaard, H. G., Kroll, J. H., Seinfeld, J. H., and Wennberg, P. O.: Isoprene photooxidation: new insights into the production of acids and organic nitrates, Atmos. Chem. Phys., 9, 1479-1501, doi:10.5194/acp-9-1479-2009, 2009.

Pickering, K. E., Wang, Y., Tao, W., Price, C., and Müller, J.: Vertical distributions of lightning $\mathrm{NO}_{\mathrm{x}}$ for use in regional and global chemical transport models, J. Geophys. Res., 103, 31203-31216, 1998.

Possell, M., Hewitt, C. N., and Beerling, D. J.: The effects of glacial atmospheric $\mathrm{CO}_{2}$ concentrations and climate on isoprene emissions by vascular plants, Global Change Biol., 11, 60-69, 2005.

Price, C. and Rind, D.: A simple lightning parameterization for calculating global lightning distributions, J. Geophys. Res., 97, 9919-9933, 1992.

Purves, D. W., Caspersen, J. P., Moorcorft, P. R., Hurtt, G. C., and Pacala, S. W.: Human-induced changes in U.S. biogenic volatile organic compound emissions: evidence from long-term forest in- 
ventory data, Glob. Change. Biol., 10, 1737-1755, 2004.

Pye, H. O. T., Liao, H., Wu, S., Mickley, L. J., Jacob, D. J., Henze, D. K., and Seinfeld, J. H.: Effect of changes in climate and emissions on future sulfate-nitrate-ammonium aerosol levels in the United States, J. Geophys. Res., 114, D01205, doi:10.1029/2008JD010701, 2009.

Racherla, P. N. and Adams, P. J.: Sensitivity of global tropospheric ozone and fine particulate matter concentrations to climate change, J. Geophys. Res., 111, D24103, doi:10.1029/2005JD006939, 2006.

Rind, D., Lerner, J., Jonas, J., and McLinden, C.: Effects of resolution and model physics on tracer transports in the NASA Goddard Institute for Space Studies general circulation models, J. Geophys. Res., 112, D09315, doi:10.1029/2006JD007476, 2007.

Sanderson, M. G., Jones, C. D., Collins, W. J., Johnson, C. E., and Derwent, R. G.: Effect of Climate Change on Isoprene Emissions and Surface Ozone Levels, Geophys. Res. Lett., 30, 1936, doi:10.1029/2003GL017642, 2003.

Sitch, S., Smith, B., Prentice, I. C., Arneth, A., Bondeau, A., Cramer, W., Kaplan, J. O., Levis, S., Lucht, W., Sykes, M. T., Thonicke, K., and Venevsky, S.: Evaluation of ecosystem dynamics, plant geography and terrestrial carbon cycling in the LPJ dynamic global vegetation model, Glob. Change Biol., 9, 161$185,2003$.

Sitch, S., Cox, P. M., Collins, W. J., and Huntingford, C.: Indirect radiative forcing of climate change through ozone effects on the land-carbon sink, Nature, 448, 791-794, 2007.

Stavrakou, T., Peeters, J., and Müller, J.-F.: Improved global modelling of $\mathrm{HO}_{\mathrm{x}}$ recycling in isoprene oxidation: evaluation against the GABRIEL and INTEX-A aircraft campaign measurements, Atmos. Chem. Phys., 10, 9863-9878, doi:10.5194/acp-10-98632010, 2010.

Stevenson, D. S., Johnson, C. E., Collins, W. J., Derwent, R. G., and Edwards, J. M.: Future tropospheric ozone radiative forcing and methane turnover: The impact of climate change, Geophys. Res. Lett., 27, 2073-2076, doi:10.1029/1999GL010887, 2000.

Stevenson, D. S., Dentener, F. J., Schultz, M. G., Ellingsen, K., van Noije, T. P. C., Wild, O., Zeng, G., Amann, M., Atherton, C. S., Bell, N., Bergmann, D. J., Bey, I., Butler, T., Cofala, J., Collins, W.J., Derwent, R.G., Doherty R.M., Drevet, J., Eskes, H. J., Fiore, A. M., Gauss, M., Hauglustaine, D. A., Horowitz, L. W., Isaksen, I. S. A., Krol, M. C., Lamarque, J.-F., Lawrence, M. G., Montanaro, V., Müller, J.-F., Pitari, G., Prather, M. J., Pyle, J. A., Rast, S., Rodriguez, J. M., Sanderson, M. G., Savage, N. H., Shindell, D. T., Strahan, S. E., Sudo, K., and Szopa, S.: Multimodel ensemble simulations of present-day and near-future tropospheric ozone, J. Geophys. Res., 111, D08301, doi:10.1029/2005JD006338, 2006.
Stocks, B., Fosberg, M. A., Lynham, T. J., Mearns, L., Wotton, B. M., Yang, Q., Jin, J. Z., Lawrence, K., Hartley, G. R., Mason, J. A., and McKenney, D. W.: Climate change and forest fire potential in Russian and Canadian boreal forests, Clim. Change, 38, 1-13, 1998.

Swetnam, T. W.: Fire history and climate change in giant sequoia groves, Science, 262, 885-889, 1993.

Tsigaridisa, K. and Kanakidou, M.: Secondary organic aerosol importance in the future atmosphere, Atmos. Environ., 41, 46824692, 2007.

Turner II., B. L., Meyer, W. B., and Skole, D. L.: Global land use/land cover change: towards an integrated study, Ambio, 23, 91-95, 1994.

Turner II, B. L., Skole, D., Sanderson, S., Fischer, G., Fresco, L., and Leemans, R.: Land-use and land-cover change science/research plan, no. 7, in: IHDP Report, 1995.

Wang, Y., Jacob, D. J., and Logan, J. A.: Global simulation of tropospheric $\mathrm{O}_{3}-\mathrm{NO}_{\mathrm{X}}$-hydrocarbon chemistry: 1. Model formulation, J. Geophys. Res., 103, 10713-10725, 1998.

Wang, Y., Jacob, D. J., and Logan, J. A.: Global simulation of tropospheric $\mathrm{O}_{3}-\mathrm{NO}_{\mathrm{x}}$-hydrocarbon chemistry: 1. Model formulation, J. Geophys. Res., 103, 10713-10725, 1998.

Wesely, M. L. and Hicks, B. B.: Some factors that affect the deposition rates of sulfur dioxide and similar gases on vegetation, J. Air. Pollut. Control Assoc., 27, 1110-1116, 1977.

Wesely, M. L.: Parameterization of surface resistance to gaseous dry deposition in regional-scale numerical models, Atmos. Environ., 23, 1293-1304, 1989.

Wu, S., Mickley, L. J., Jacob, D. J., Logan, J. A., Yantosca, R. M., and Rind, D.: Why are there large differences between models in global budgets of tropospheric ozone?, J. Geophys. Res., 112, D05302, doi:10.1029/2006JD007801, 2007.

Wu, S., Mickley, L. J., Leibensperger, E. M., Jacob, D. J., Rind, D., and Streets, D. G.: Effects of 2000-2050 global change on ozone air quality in the United States, J. Geophys. Res., 113, D06302, doi:10.1029/2007JD008917, 2008a.

Wu, S., Mickley, L. J., Jacob, D. J., Rind, D., and Streets, D. G.: Effects of 2000-2050 changes in climate and emissions on global tropospheric ozone and the policy-relevant background surface ozone in the United States, J. Geophys. Res., 113, D18312, doi:10.1029/2007JD009639, 2008b.

Yienger, J. J. and Levy, H.: Empirical model of global soil-biogenic $\mathrm{NO}_{\mathrm{x}}$ emissions, J. Geophys. Res., 100, 11447-11464, 1995. 